"I strapped on my snowshoes and with a rabbit snare and stick to hold this big bird away I went to help him. When I got to him I was afraid that he might decide to bite me. I snared his head but while I was busy doing this he got me by the hand with the claws from both feet. My woolen gloves were no protection I can assure you. My next thought was, what do I do now in this predicament? With my free hand I took the stick and put it next to his feet. He removed his claws from my hand (which really hurt and was bleeding) and sank his claws into the tick instead. Then, with my hand that was not wounded I grabbed both his feet above the claws, and held him upide down while I attempted to free his wing from the barbed wire.

("The barbed wire strand was about three feet from the ground but was hanging loose about 18 inches above the snow. The owl may have tried to land on the wire and caught his wing in the process. I first noticed the owl about noon hour on a calm day with temperature about 30 above).

"At this stage of the game it would pe safe to say that my heart was beating bout as fast as it could. I didn't want o injure the owl anymore than he was, ut it was necessary to pull his wing ree of the wire. Finally, I did free him ind then turned him away from me, ind he fluttered away about 10 feet. He then turned around and looked at ne. I turned around and walked home o nurse my hand.

"I got in touch with the local conseration officer who captured the owl he following day. I learned from the fficer that the owl had followed me nost of the way home. Neighbors tell ne that the owl had been in this area or the past two weeks and had no fear of buildings, houses, etc. Knowing of his owl's fate now, I wish I had been if more assistance to him.

"I would appreciate your writing a ote for publication in your local atural history bulletin. You may wish note that my rescue of the Great jray Owl was an ordeal for both of us, r I am 70 years of age."

\section{LONGEVITY RECORD FOR BLACK-CROWNED NIGHT HERON: 16-1/2 YEARS}

\author{
by C. STUART HOUSTON*
}

On July 7, 1956, I banded 21 nestling Black-crowned Night Herons in a small colony located by nature columnist Doug Gilroy, along the banks of the Qu'Appelle River, 6 miles east of Craven, Saskatchewan $\left(50^{\circ} 40^{\circ} \mathrm{N}-104^{\circ} 30^{\circ} \mathrm{W}\right)$.

On February 15, 1973, one of these herons, bearing band $N_{0}$. 547-24244, was found sitting on a fence, apparently unable to fly, near the Cape Romain National Wildlife Refuge, Awendaw, South Carolina $\left(32^{\circ} 40^{\prime} \mathrm{N}\right.$ $\left.79^{\circ} 50^{\circ} \mathrm{W}\right)$. It was brought by a neighborhood youngster to Burkett S. Neely Jr., the refuge manager, but died during the night.

This bird reached an age of 16 years, 7 months and 8 days. The band itself was in excellent condition and remains on the heron, which has been mounted for public display at the refuge. The oldest heron of this species that I have located in the literature is one that reached 14 years, 10 months, listed by Rydzewski in The Ring 34: 178, 1963.

This was, however, a short-lived record. Less than 5 months later, on July 9, 1973, a Black-crowned Night Heron banded as a nestling in Ohio near the southwest corner of Lake Erie, was collected for pesticide analysis within 30 miles of its banding place. It had been banded on June 6 , 1952, and was slightly more than 21 years old. I am indebted to Jay $M$. Sheppard of the U.S. Bird Banding Laboratory for forwarding this record and to Laurel F. Van Camp, naturalist at the Crane Creek Wildlife Experiment Station for permission to publish this record.

*86.3 University Drive

Saskatoon, Sask. S7N ()J8. 